\title{
An African Reformation
}

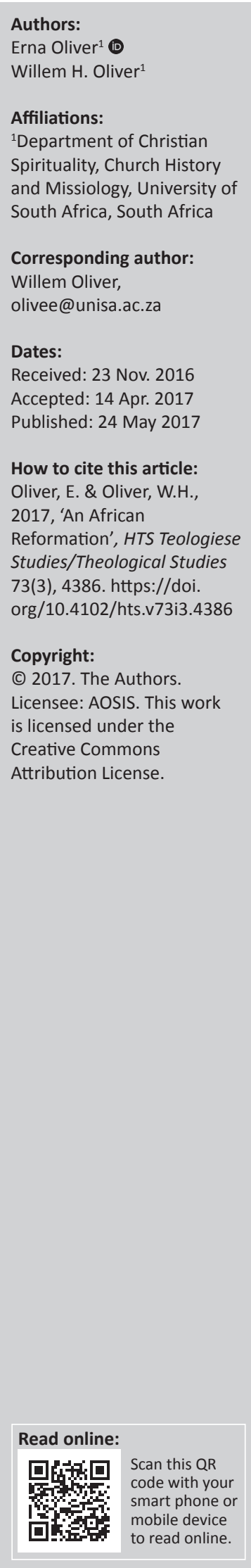

The year 2017 is the year in which the Reformation, started by Martin Luther, is celebrating its 500th birthday. This depicts a milestone in the life of the Church of the Reformation and also in the life of Christians worldwide. This is a good time to ponder on the epistemological question of the validity and necessity of the (European) Reformation (i.e. improvement, renovation or change). If this question is answered in a positive way, then it could bring us to the realisation that the time is ripe for an African Reformation. This article will argue that this is indeed the case. A reformation, transformation and change is needed for the African Christian context. However, the question could well be asked: Who will be the 'second Luther?'

\section{Introduction}

I'm looking for a second reformation.

The first reformation of the church 500 years ago was about beliefs.

This one is going to be about behaviour.

The first one was about creeds.

This one is going to be about deeds.

It is not going to be about what does the church believe,

but about what is the church doing.

(Beliefnet 2005)

The world is in a rat race. However, the celebration of a significant historical event should enable people and institutions to such an extent that they will make time to ponder and to rethink the implication(s) and significance of that event upon the functioning and effective proclaiming of the Gospel in their circumstances and environments. The (European) Reformation, and especially its 500th commemoration in 2017, is such an event that should be celebrated with respect and an open, reflective mind. Existential and epistemological questions have to be asked about this Reformation: What was the validity of the Reformation? Was it really necessary? Was it viable? What does it expect us to do/act today in a 'post-Christian world' (Schaeffer 1969:9)? If the European Reformation was valid/necessary/viable, does it evoke us to act accordingly? What would it mean to 'act accordingly'? This article will argue that an African Reformation (in African terms maybe, a '[spiritual] Revolution' - cf. Schaeffer 1969:9) ${ }^{1}$ is necessary for the Church to survive and keep its mission alive. The geographic focus of the article is Africa, which is seen by the West as the Dark Continent that has/had no or very little to contribute to Christianity, both historically and in the current development of society.

The sequence of the headings in this article is done from a historical perspective. During the Early Christian Era, Africa already stood tall as one of the leaders in the development of Christianity, with exponents like Apollos, John Mark and the heads of the catechetical school in Alexandria, especially Clement and Origen. The Arab invasion of 642 brought an abrupt end to most of the early inputs of Christianity in Africa, leaving this continent 'to rest from Christian development and growth' for almost a millennium. During this time, the Reformation took place in Europe and it should be noted that it did not have any effect on Africa at that time. Then came the colonisation of Africa and, entrenched/coupled with it,

\footnotetext{
1.According to Schaeffer (cf. also Beckham 1995:232-235), a spiritual revolution follows an equation as follows:

Reformation of Doctrine

Revival of God's Spirit

+ Remnant of God's Committed

+ Restoration of the New Testament Design

= Spiritual Revolution
} 
missionary work. The article then discusses a few unofficial 'second Reformations' that took place around the globe, before looking at the current situation in Africa and the need for an African Reformation. The conclusion asks the vital question: Who will start this Reformation?

\section{Africa's part in the foundation of Christianity and Christian theology ${ }^{2}$}

Africa was/is not the Dark Continent - an 'enduring' attribute given to this continent during the middle of the 19th century (Brantlinger 1985:166-203) - with no contribution made to the history of the world. ${ }^{3}$ In fact, Africa has very much to be proud of:

- Africa was the cradle of mankind (cf. Oppenheimer 2003).

- Central and southern Africa is seen as a 'single origin for modern languages or the main origin under a polygenesis scenario' (Atkinson 2011:347).

Three theological facts should be added to these two major contributions:

- The preacher, Apollos, 12 times referred to in the New Testament, was born in Alexandria and also preached there.

- The evangelist, John Mark, the author of the oldest Gospel in the New Testament, was born in North Africa and preached in Alexandria.

- Africa formed part of the foundation of earliest Christianity and Christian theology. This is being said in the light of a statement made by Oden in 2007, that quite a few 'decisive intellectual achievements of Christianity were explored and understood first in Africa before they were recognized in Europe, and a millennium before they found their way to North America' (Oden 2007:9)

\section{Apollos, a 'servant of Christ'}

Apollos, an early precursor to the catechetical school in Alexandria was, according to Acts $18: 24$, born in Alexandria, most probably at the beginning of the 1st century. Paul, who met Apollos in Ephesus when the latter was preaching there, referred to himself and Apollos in 1 Corinthians 4:6 as examples of 'servants of Christ', calling Apollos a 'brother' in 1 Corinthians 16:12. Schaff (1885:567) regarded the rise of the catechetical school in Alexandria as an outcrop of the learning and piety of Apollos and claimed that the character and words of 'this brilliant Alexandrian' had a significant influence on converts in Alexandria.

2.Some positivistic scholars are giving Africa 'a little' more than her due, like Burton (2007:111) who claims that the majority of the Bible was penned on African soil and that Christianity was born in 'Biblical Africa'.

3.This is being said with the following words in mind: For the African to cultivate an inferiority complex that he is inferior to other races, is to sign the death warrant of Africans. An emancipation is therefore essential. Let the African know that he had a ( global past and that he has a glorious future (Azikiwe 1968:165). Africans have been mis-educated. They need mental emancipation so as to be re-educated to the rea needs of Renascent Africa (Okon 2014:206).

\section{An African contribution to the Bible}

According to the African memory, ${ }^{4}$ Africa has played a significant role in Early Christianity (cf. Oden 2011a, 2011b). The memory states that the author of the first Gospel - John Mark - was born in North Africa, close to Cyrene, in the region of Cyrenaica between 5 and 15 CE (Oden 2011a:21, 45), being part of a family of Diaspora Jews (Oden 2011a:46). Mark's father, Aristopoulos, whose brother was Barnabas (who later joined the Apostle Paul on his first Missionary Journey), and their cousin, Strapola (who later married the Apostle Peter - cf. Sawirus ${ }^{5}$ History of the Patriarchs of Alexandria, 135-137) lived in that region before they fled to Jerusalem (Oden 2011a:20, 45, 46, 48) after tribal conflicts broke out in Cyrenaica (Oden 2011a:20, 21, 36). In Jerusalem, Mark and his mother, Mary, became part of the followers of Jesus of Nazareth (Oden 2011a:21) as they formed part of his core circle (Oden 2011a:51). References to the house of Mary, where the earliest Christians had frequented, are found in Acts $1-2$ and 12 .

According to Clement of Alexandria, in his Hypotyposeis 8 (quoted in Hist Eccl 2.16.1), Mark was in Rome with Peter, where he wrote his Gospel in response to a request which came from the laity of Rome. However, in his Adumbrations (on 1 Peter 5:13), Clement stated that when Mark was with Peter in Rome, the high Roman military officials requested him to write down what Peter has preached, and this became his Gospel (cf. also Oden 2011a:195-196). As Mark had followed Peter for a long time, he wrote what Peter had preached.

Another legacy left by Mark to the African Church was through the eucharist. According to Oden (2011a:246), the 'Markan Eucharist has been at the chore of the central rite of African Christian worship from the outset, from which other liturgies (of Basil, Gregory and Cyril) presumably derived'. Mark was also the first Christian martyr on African soil as he was martyred in Alexandria (cf. Hist Eccl 2.16), setting the example for many martyrs, especially in Africa, to follow him. According to the African memory, Mark was martyred before $68 \mathrm{CE}$, the date when Paul and Peter were both martyred in Rome (Oden 2011a:154-157). Many African martyrs were to follow this example: 'These African martyrs received the apostolic vision from the beginning through Mark. They learned that the truth of the gospel is worth dying for' (Oden 2011a:172).

\footnotetext{
4.The phrase African memory Oden is a 'two-thousand-year-long history of a way of remembering' (Oden 2011a:27). The African memory depicts the way in which remembering' (Oden 2011a:27). The African memory depicts the way in which
Africans 'historically viewed events and persons, and how they still characteristically Africans 'historically viewed events and persons, and how they still characteristically
remember them' (Oden 2011a:27). Oden (2011a:27-28) supplies five characteristics remember them' (Oden 2011a:27). Oden (201
for an event to belong to the African memory:

- The event should be commonly remembered in Africa.

- The event would be remembered in the same or similar ways.

- Consent to the event is not enforceable.

- The event should be remembered by many generations of Africans.

- The event has to be told in more than one indigenous language of Africa.

5.Sawirus (Severus) ibn al-Maquffa, bishop of al-Ashmunein was one of the most important sources for the Coptic memory of Mark (Oden 2011a:66). He wrot between 955 and 987 and is traditionally celebrated as the author of the classic between 955 and 987 and is traditionally celebrated as the author of the classic History of the Patriarchs of the Coptic Church in Alexandria (HP) (cf. Oden 2011a:66) He made use of Euseb writings of Cyril the Great, when he wrote his lengthy chronicle on the history of 'Saint Mark, the Disciple and Evangelist, Archbishop of the great city of Alexandria, and first of its Bishops' in his HP 135 (cf. Oden 2011a:33, 67).
} 


\section{The catechetical school in Alexandria ${ }^{6}$}

Malaty (1995:208), supported by Pope Shenouda III (cf. Oden 2011a:24), refers to the 'first historians' - Eusebius ${ }^{7}$ and Jerome (who was one of the later attendees of the catechetical school) - who stated that Mark, one of Jesus' followers in Jerusalem (referred to by Clement as 'the follower of Peter' in his Hypotyposeis 1.1), 'founded' the school in the middle of the fifth decade CE (cf. De Viris Illustribus 8; 11 where Jerome referred to the school as a 'church'; cf. Malaty 1995:208). Malaty (1995:10; cf. also Oden 2011a:243) interprets Hist Eccl 5.10 that Mark was the founder of the school and further bases his argument on Hist Eccl 2.16 in which Eusebius mentions that Mark had been sent to Alexandria to preach there. After Mark, a probable succession of 17 other heads would follow (cf. Oliver 2015) before the demise of the school by the end of the 4th century (cf. Van den Broek 1996:205).

Despite the fact that catechetical schools in the Early Church Era had very limited influence (cf. El Masri 1982:13), the school in Alexandria became the centre of 'intense intellectual life' in the Roman Empire (El Masri 1982:13-14). Together with the school in Antioch, founded much later - in the latter half of the 3rd century - these were the two major centres for the study of theology and Biblical exegesis during the time of the Early Church. The theological school in Carthage (founded in the second half of the 2nd century) would never be on the same level as these two.

During the Early Church Era, Alexandria, the capital of Egypt, was the leading city in Africa and for some time even the centre of Christianity in the Roman Empire. Alexandria was also the centre of intelligence in the Roman Empire for a considerable time. The two heads of the school who were the most prominent were Clement and Origin. The future of Christianity in general was maximally indebted to the writings of these two religious giants:

for without their singular achievements in systematizing Christian thought and belief, it is easy to speculate that Christianity might have meandered on as just another religion among many. At best, formalized Christian religion would have been delayed by several hundred years until the arrival - again fortuitously - of Ambrose, Augustine and Jerome in the dying days of Rome. (Fogarty 2004:144)

\section{Africa as the cradle of Christian theology}

Without elaborating too much on this theme, it can be stated that, during the time of the school in Alexandria, the heads published an extensive amount of material, which was of a polemic, an informative and an apologetic character

6.Notwithstanding the arguments of certain scholars that the was no catechetical school in Alexandria, or that it only existed for a few years (cf. Scholten 1995. Tlok 2006:112-124: Van den Broek 1995:43. Van den Hoek 1997:59-87) many others figure that a catechetical school of some sort must have existed in Alexandria.

7.Eusebius of Caesarea, a Roman historian referred to as the 'first church historian' and also as the 'father of Church History' (Doergen 1937:446-448; cf. Verdoner 2014:239), wrote a 4th-century 10-volume work called Historia Ecclesiastica (Hist EcCl).
(Barrett 2011:4). They mostly used the allegorical method for the interpretation of Scriptures (McGrath 2013:32). These writings of the heads laid the foundation for both the theology and the practice of Christianity in the Roman Empire (Fogarty 2004:127). This contributed to the fact that the school had such a tremendous influence on Christianity, as it was the first intellectual institution in Africa and the Roman Empire where scholars could theologise about God.

A short reference to the First Ecumenical Council held in Nicaea in 325 CE also supports the argument: this Council was held outside of Africa, but under the full influence of African theology. The Council needed a theological creed to defend Christianity against heresies like Arianism (El Masri 1982:104) and appointed three members to ensure the effective wording of the creed: these members were Alexander, the Bishop of Alexandria, his deacon Athanasius and Leontius, the Bishop of Caesarea in Cappadocia. However, Athanasius had already worded a confession on his own (Isichei 1995:24), and that became the creed that was later accepted at the Council.

Another decision taken by the Church in Alexandria was that rebaptism was wrong. This was a principle highlighted by Peter the Martyr during the time of Bishop Dionysius (El Masri 1982:106) in his 14 canons of Church Discipline 'during the fourth year of the persecutions' (El Masri 1982:74). The Churches of both the East and the West respected these canons (El Masri 1982:75). This principle was also accepted by the Nicaean Council Fathers (El Masri 1982:106).

\section{The Arab invasion of Africa}

In $642 \mathrm{CE}$, everything changed in and for Africa. The divisions within the broader Christian community at the time in Africa, as well as the misunderstanding that the Arabs were simply another Christian sect (Isichei 1995:43), paved the way for them to take the land with almost no resistance. The Monophysite Church of the Copts, to which only $10 \%$ of the population belonged, was the only Church being recognised by the new rulers. With this invasion, Christianity was 'laid to rest' in Africa for almost a millennium before it arose again to take its rightful place on the continent, after the appearance of the missionaries.

\section{The reason/s for the European Reformation}

Martin Luther was a German monk born in the late-15th century. His reason/s for nailing his 95 theses to the door of the All Saints' Church in Wittenberg 8 on 31 October 1517, which marked the real beginning of the European Reformation, was that the Church of his time - the Roman Catholic Church - was straying from the Word of God. The letter he sent to his bishop, Albert of Mainz, contained his 95 theses, which he called Disputation of Martin Luther on the

8.Cognisance is taken of the fact that scholars like Krämer and Trenkler (1997) and Ritter (1985) are arguing that it is not true that Luther has posted his theses on the door. 
Power and Efficacy of Indulgences, thereby putting forward his main concern with the Church of his time - the sale of indulgences mainly by John Tetzel to the laity in order to raise money for the Pope to rebuild the St. Peter's Basilica in Rome (cf. Aland 1967). In his 95 theses, Luther did not attack his Church or fight with them, but in a humble way he argued against the decision of his Church to take the place of God in remitting the sins of their members when these pay a fee for their remission. He stated in his theses that only God can remit sins (see theses $1 ; 6 ; 7 ; 37$ ), and those who think that they can buy their salvation with indulgence letters 'will be eternally damned' (thesis 32). In fact, 'papal indulgences cannot remove the very least of venial sins as far as guilt is concerned' (thesis 76). Luther rather motivated people to do good deeds instead of buying indulgences (thesis 43), because through good deeds mankind becomes better (thesis 44). $\mathrm{He}$ added that, if one ignores good deeds and rather buys indulgences, he is buying God's wrath (thesis 45). Indulgences are no treasure, as the 'true treasure of the church is the most holy gospel of the glory and grace of God' (thesis 62). The graces of the Pope rather are 'the gospel, spiritual powers, gifts of healing, etc.' (thesis 78). Close to the end of his theses, Luther put the heart of his argument very visible on the table: 'Let him who speaks against the truth concerning papal indulgences be anathema and accursed. But let him who guards against the lust and license of the indulgence preachers be blessed' (theses $71 ; 72$ ).

When answering the questions about the validity/necessity/ viability of the Reformation, and whether it expects us to do something ('act accordingly') today, the above information must seriously be taken into account. So, did Luther really have a reason to stand up and talk? Having discussed the theses of Luther cursory, it seems as if he had enough reason to reprimand the Church of his day for not acting according to God's will, even though he abstained from doing so and chose to argue in a humble, but firm way. Luther displayed the courage of his convictions by standing up for what was right according to the Bible, and in 95 theses he made his arguments visible. This was no easy road he chose to walk, but he did it, with all the devastating consequences that followed for him. The centuries that followed this Reformation acted as proof that Luther did the right thing.

\section{The colonisation of Africa and missionary work}

Despite various forms of resistance by countries in Africa, the continent was fully colonised ${ }^{9}$ by the early-20th century, mainly for economic, but also for political and social reasons (Iweriebor 2002:3-28). Only Ethiopia and Liberia remained free (for most of the time). The political power struggle in Europe was between the forces of Britain, France, Germany, Belgium, Italy, Portugal and Spain. On social level, there were many problems in Europe, like unemployment, poverty, homelessness and social displacement from rural areas. The foreign rule by an external power, which culminates in the control and exploitation of the conquered people'. reason for this was that many people were unable to become part of the new capitalist industries in Europe - that 'surplus population' had to be moved out of the countries of Europe. This could be the reason for the Berlin Conference (also called the Congo Conference or West Africa Conference - cf. Heath sa.) that was held during 1884-1885 at the request of Portugal and organised by German chancellor Otto von Bismarck. He summoned representatives from Austria-Hungary, Belgium, Denmark, France, Britain, Italy, the Netherlands, Portugal, Spain, Sweden-Norway, the Ottoman Empire and even the United States to attend the so-called Scramble for Africa (cf. Pakenham 1991). Within half a century, Europe conquered almost the entire continent (Pakenham 1991:xxi).

Missionary work was done in Africa together with and aided by colonialism (Mbiti 1969:231; cf. Okon 2014:192, 198; Sanneh 1990:88). Christianity 'with various strands and variegated manifestations' (Okon 2014:192) was the main religion being presented. Unfortunately, the colonial image attached to the missionary work, affected the good intentions of the missionaries (Okon 2014:198), as they were seen as agents of imperialism (Kalu 1980:7; Rodney 1972:277). In West Africa, the people had the conviction that the missionaries 'had a dual purpose to promote legitimate trade between Africans and Europeans and to convert Africans to their own religion' (Crowder 1962:111).

On a more positive note, Kalu (1980:182) argues that the missionaries and the colonial governments did not have the same intentions, as the colonists did not establish the colonies for missionary purposes. According to him the purposes of the colonists and the missionaries often differed in content, philosophy and in execution. Okon (2014:206) adds to this: 'It is poor historical thinking to erase the numerous and comprehensive achievements of the missionary enterprise because of human shortcomings and failures'.

Still the theory of conversionism was a reality, depicting the:

best way to wipe away darkness, heathenism and collective ignorance from Africa was to impose European culture, religion and philosophy on Africa by force. Africans must be compelled to abandon their religion and culture, [and] adopt western values. (Okon 2014:203; cf. Crowder 1968:5)

It is because of this theory and its implementation that many Africans regarded the Bible as a western document depicting a western (European) culture. Mills (1990) refers to this in a literature review of the modern age:

The modern age has retained the cultural heritage it received from the revolutionary epochs of the Renaissance and the Reformation, working out the consequences of both their emphases on the freedom and value of humanity and their concern with the biblical messages of judgment and grace. The continuing cultural struggles that have thus characterized the modern age have been reflected and recorded in the plethora of literature of all types that has been produced in increasing volume. The place of the Bible as the great fundamental document of Western culture (emphasis added) may be clearly seen in almost all of the literature, sometimes in a positive way but often in reaction and rejection. (p. 107) 
Although the Bible is an Ancient Near-Eastern document, created and written down at a time when one could hardly talk of 'The West', the fact that Rome (and the Roman Catholic Church) 'took over' from Jerusalem and later on Alexandria as the centre of Christian religion and theology, deprived the Bible from its origin and wrongfully gave a western colour to the Word of God. Later on, Jesus was even depicted to be a white man with long blond hair, in order to fit the European (and later the American) picture better (cf. Oliver 2014).

Notwithstanding all the negative attributes of the missionaries, one thing is clear: they introduced the bigger part of Africa to modern Christianity.

\section{Interlude: A few second/other reformations}

Different parts of the world boast with what is generally called, a 'Second Reformation':

- Short after the Reformation started, in the late 1540s there were already people who differed from what was said in the original Reformation (Schilling 1992:259). They were concentrated in 'middle and western Germany with offshoots in the west and northwest' (Schilling 1992:248) as an 'expression of confessionalization' (Schilling 1992:271), and it was essentially 'an elite phenomenon' (Schilling 1992:283), also referred to as a 'Second Reformation' (cf. Schilling 1992:259ff.).

- The Nadere Reformatie, also referred to as the 'Dutch Second Reformation' or 'Further Reformation' occurred between 1600 and 1750 and was much influenced by Puritanism and Pietism. The two leading figures were Gisbertus Voetius and Wilhelmus a Brakel (De Reuver 2007).

- From the 1820 s onwards, there was an evangelical campaign in Ireland and England, organised by fundamentalists. This was an unsuccessful campaign to proselytise Roman Catholics (cf. Whelan 2005).

- In the United States, there were at least four Great Awakenings, occurring between the beginning of the 18th century and the end of the 19th century, led by Evangelical Protestants (cf. Kidd 2007).

None of these reformations or revivals ('awakenings') was officially named Second Reformation or stood the test of time like the (first) Reformation. However, it is necessary to just note them, to acknowledge that they did take place and could also be used as referencing sources when the current situation is analysed. Also, it should be noted that none of these reformations are directly linked to the African continent or its unique circumstances.

\section{The current situation in Africa}

As has been argued in this article, Africa is not the Dark Continent as mostly depicted by the West. Africa (specifically northern Africa as part of the Roman Empire) has a theological history that Europe and the Americas can only dream of. This continent was indeed part of the foundation of Christian theology and history. Granted, after the Arab invasion in the 7th century, Africa has stagnated on the level of Christianity for the best part of a millennium, giving Europe and the Americas the chance to become big on theology. During this time Europe also experienced its Reformation, of which Africa knew very little, and therefore with little influence on this continent at that time. Should there therefore be a Reformation in Africa, it should be called the (first) African Reformation, as this continent was not really influenced by the first (European) Reformation.

The question should be asked whether there is a need for a Reformation/(spiritual) Revolution in Africa and what will be the main determinant for such a drastic step? Look at the following: In Africa there is a myriad of Christian Church groups, each with its own 'truth' and each with its own diversions into smaller groups. There are the Roman Catholic Church, the AICs, the Protestant/Reformed Church family including the Pentecostals and Seventh-day Adventists, the Anglican and all English/England Churches and the Charismatic Church groups - to name but a few main groups. Many of these Church groups are affiliated to an Ecumenical Council, thereby stating that they are actually united with other Christian Churches belonging to that Church group. However, the unity/'peace' is only seen at the Council and not outside. Luther has already warned against this false peace in his 92nd thesis, referring to the Bible: 'Away, then, with all those prophets who say to the people of Christ, "Peace, peace," and there is no peace! (Jr 6:14)'.

For the past decade, the Megachurch trend is very much alive in Africa, with Churches mostly belonging to the Pentecostal groups, modelled on their counterparts in the United States (Cocks 2014), as well as Charismatic groups. Cocks (2014) states that some of these Megachurches can hold up to 200000 worshipers. Examples are found in Nigeria (The Deeper Life Christian Ministry; The Living Faith Church; The Redeemed Christian Church of God), Kenya (Jesus Celebration Center) and even in South Africa (Rhema Bible Church), to name but a few. Although most of these Churches are prosperity gospel Churches (cf. Mennoknight 2013), they are at least bringing people together from all over the Christian spectrum. Something to ponder on: are these Churches really bringing people closer to God and to his Word?

When one looks at this, one realises that the Church of God in Africa:

- is scattered and equipped with many different 'truths' (in fact dogmas)

- displays no unity as it should:

- no unity in their basic beliefs in God

- no unity in their creeds

- no physical unity

- has diverted away from the Word of God to other commodities like money and power and stature. 


\section{An African Reformation/Revolution?}

From the above, it seems as if a Reformation is due for the Church of God in Africa. But what would it entail? This is the first question to be answered in order to start thinking about a Reformation. We can apply the words of Trueblood (1952) on Africa:

Now ... we can, if we will, change gears again. Our opportunity for a big step lies in opening the ministry to the ordinary Christian in much the same manner that our ancestors opened the Bible reading to the ordinary Christian. To do this means, in one sense, the inauguration of a new Reformation while in another it means the logical completion of the earlier Reformation in which the implications of the position taken were neither fully understood nor loyally followed. (p. 32)

Rick Warren argues that the first Reformation was about beliefs and creeds - more specifically, it was about an adjustment to the creed of the Catholic Church, to sell indulgences in order to get a Basilica repaired. Someone had to stand up against it - and Martin Luther was prepared to do just that. It is very important to take note that Luther was not that prominent a person in his Church when he stood up for what was right. He was actually a common monk in the Roman Catholic Church at that time.

The Reformation in Europe ended up in the split of the world Church - the Roman Catholic Church - resulting in the formation of the Reformed Church group as a second Christianity group. This group/Church interpreted and expressed its Christianity in the three well-known solas: Sola Scriptura [the Scripture alone], Sola Fide [faith alone] and Sola Gratia [only (God's) grace], being expanded with two more solas - Solus Christus/Solo Christo [Christ alone/through Christ alone] and Soli Deo Gloria [glory to God alone].

The African Reformation must break away from creeds and dogma because, especially nowadays, people like to play with words, which could be a meaningless endeavour without practical influence and empowerment. The African Reformation must indeed be about deeds, in line with the 44th thesis of Luther: Because love grows by works of love, man thereby becomes better. The African Reformation Church must stand up and be seen and heard - in unity. Whereas the European Reformation ended up in a Church split, the African Reformation must be about a united Church working together on the basis and for the sake of Christ, with one united focus: to combat our common enemy - the devil and all her and/or his manifestations - by ministering the Word of God to everybody on our continent. The implication is that the African Reformation Church will have to start teaching its congregants to really have knowledge of the Word of God - not dogmatic knowledge instilled by different Churches, not a superficial know-how of some texts in the Bible, sometimes even mixed with culture and traditions, but a knowledge of the heart of God and how to help others to also become real children of God.
Africa needs a Reformation, created through a thorough reading of the Bible and understanding of the message of God within its pages (Shaull 1991:51-53). Africa really needs a Sola Scriptura experience. The African Reformation Church should emit the following attributes (Beckham 1995:26-27):

- less isolated from the world in which it lives

- more relevant to the needs of society - especially the sick, the poor and the jobless

- more compassionate in the way it uses money and manpower

- reaching more people instead of promoting better programmes

- less materialistic with its huge buildings and debts

- more redemptive and less political

- less influenced by the world it is called to influence.

All these attributes are focused on behaviour and deeds, displaying a compassion for God's people on earth.

\section{A common creed?}

We have already stated that the African Reformation must not revolve around a creed, but around deeds. Therefore, this is not high on the priority list. The African Reformation Church must first find its feet and be well-established before considering a creed.

Some creeds have seen the light in Africa, or have an African origin. The first creed, as has already been mentioned, was the Creed of Athanasius, which is still one for the Reformed creeds. Two other creeds were published:

- In 1960, the Maasai Creed was composed by the Maasai people of East Africa in collaboration with missionaries from the Congregation of the Holy Ghost. ${ }^{10}$ This is a rather short three-point creed, confessing the triune God.

- The Confession of Belhar ${ }^{11}$ in South Africa was published in 1986 and emerged from the struggle against apartheid in this country (cf. McGarrahan 2008).

Both these creeds are focused on the Holy Trinity, although the second one has political undertones because of its origin. Both these creeds are adopted by certain Christian groups/ Churches for use during sermons, but none of them has a common acceptance in Africa. When the African Reformation Church creates its own creed, it should be based on the Bible and focused on the behaviour and deeds of the people. It should contain, inter alia, the following basic facts:

- The Holy Trinity - the God we worship:

- The Father who created the universe and humankind.

- The virgin birth of Jesus, his death on the cross, his resurrection from the dead and his ascension into heaven - thereby creating eternal life for his followers - as well as his second coming.

- The Holy Spirit who lives inside us and guides us every day.

10.The wording of this Creed can be found in Nearing Colob (2014)

11.The wording of this Creed can be found in Confession of Belhar (1986). 
- The focus of the African Reformation Church: behaviour and deeds.

- Personal: God wants me to be a change agent for him in word and deed (Isa 6:8-9).

\section{Conclusion}

Africa has a history to be proud of: events from its historical timeline clearly indicate that this continent can stand up and be counted. However, not only scholars from the West, but 'tragically many African scholars and church leaders also have ignored their earliest African Christian ancestors' (Oden 2007:11). Not even devastating events like the Arab invasion of 642 and the colonisation of the 19th and 20th centuries should stand in the way of this continent to appropriate to itself what rightfully belongs to it. As Africa took the lead during the Early Christian Era in creating a Christian theology that would stand the test of time, in the same way this continent needs to 'change gears again' (in Trueblood's words) and take the lead in creating a unified Church - a spiritual revolution. It will take much research and many willing and able bodies and lots of blood, sweat, tears and prayers to get this venture from the ground. Hopefully, this article, together with many others published by Africans like us, will act as a first step in the right direction.

When referring to a big theological event or step that should be taken, people tend to look for Church leaders to act as trailblazers. However, this will most probably not be the case with an African Reformation - as it was not the case with the European Reformation - as Church leaders will not easily take this kind of revolutionary step. The African Reformation Church is looking for a 'commoner' like Luther, someone with the same hunger for the Word of God - a monk, a jobless outcast, someone living in a shack, someone who actually is a nobody, but someone who has the courage of her and/or his conviction to stand up for what is right. That will be the person who will lead the various Church groups in Africa to become the one united African Reformation Church.

Then I heard the voice of the Lord saying:

'Whom shall I send? And who will go for us?'

And I said, 'Here am I. Send me!'

He said, 'Go...' (Isa 6:8-9a)

\section{Acknowledgements Competing interests}

The authors declare that they have no financial or personal relationships which may have inappropriately influenced them in writing this article.

\section{Authors' contributions}

E.O. and W.H.O. equally contributed to the research and writing of this article.

\section{References}

Aland, K. (ed.), 1967, Martin Luther's 95 theses, with the pertinent documents from the history of the Reformation, Concordia Publishing House, Saint Louis, MO.

Atkinson, Q.D., 2011, 'Phonemic diversity supports a serial founder effect model of language expansion from Africa', Science 332(6027), 346-349. https://doi. org/10.1126/science.1199295

Azikiwe, N., 1968, Renascent Africa, Cass, London.

Barrett, N.C., 2011, 'The Alexandrian Catechetical School of Clement and Origen as a postmodern model for the contemporary church and theological academy', Unpublished MA dissertation, Hardin-Simmons University.

Beckham, W.A., 1995, The second reformation: Reshaping the church for the 21st century, Touch Publications, Houston, TX.

Beliefnet, 2005, Rick Warren's second reformation, viewed 20 October 2016, from http://www.beliefnet.com/faiths/christianity/2005/10/rick-warrens-secondreformation.aspx

Brantlinger, P., 1985, 'Victorians and Africans: The genealogy of the myth of the Dark Continent', Critical Inquiry 12(1), 166-203. https://doi.org/10.1086/448326

Burton, K.A., 2007, The blessing of Africa, InterVarsity Press, Downers Grove, IL.

Cocks, T., 2014, 'Nigeria's "megachurches": A hidden pillar of Africa's top economy', World News, 12 October, viewed 26 October 2016, from http://www.reuters. com/article/us-nigeria-megachurches-insight-idUSKCNOI104F20141012

Confession of Belhar, 1986, viewed 26 October 2016, from http://www.reformiert.de/ tl_files/reformiert.de/oekomene/Dokumente/belhar\%20confession.pdf

Crowder, M., 1962, The story of Nigeria, Faber and Faber, London.

Crowder, M., 1968, West Africa under colonial rule, Hutchinson, London.

De Reuver, A., 2007, Sweet communion: Trajectories of spirituality from the middle ages through the further reformation, transl. JA De Jong, Baker Academic, Grand Rapids, MI.

Doergen, H., 1937, 'Eusebius von Caesarea, der Vater der Kirchengeshichte', Theologie und Glaube 29, 446-448.

El Masri, I.H., 1982, The story of the Copts: The true story of Christianity in Egypt. Book 1: From the foundation of the Church to the Arab invasion, St. Anthony Coptic Orthodox Monastery, Newberry Springs, CA.

Fogarty, M.E., 2004, 'Egyptian Christianity: An historical examination of the belief systems prevalent in Alexandria C.100 B.C.E - 400 C.E', Unpublished MPhil dissertation, University of Stellenbosch.

Heath, E., s.a., Berlin Conference of 1884-1885, Oxford Reference, viewed 28 August 2016, from http://www.oxfordreference.com/view/10.1093/acref/978019533 7709.001.0001/acref-9780195337709-e-0467

Isichei, E.A., 1995, A history of Christianity in Africa, William B. Eerdmans Publishing Company, Grand Rapids, Ml.

Iweriebor, E.E.G., 2002, 'The psychology of colonialism', in T. Falola (ed.), The end of colonial rule: Nationalism and decolonization of Africa, vol. 4, pp. 3-28, Carolina Academic Press, Durham, NC.

Malaty, T.Y., 1995, Lectures in patrology: The school of Alexandria. Book one: Before origen, St. Mark's Coptic Orthodox Church, Jersey City, NJ.

Kalu, O., 1980, The history of Christianity in West Africa, Longman, Harlow, Essex.

Kidd, T.S., 2007, The great awakening: The roots of evangelical Christianity in colonial America, Yale University Press, New Haven, CT.

Krämer, W. \& Trenkler, G. (eds.), 1997, 'Luther', in Lexicon van Hardnekkige Misverstanden, pp. 214, 216, Uitgeverij Zwarte Beertjes, Haarlem.

Mbiti, J.S., 1969, African religions and philosophy, Heinemann, London.

McGarrahan, E.T., 2008, A study of the Belhar Confession and its accompanying letter, published by the Office of Theology and Worship General Assembly Counci Presbyterian Church (USA), viewed 26 October 2016, from http://www. synatlantic.org/wp-content/uploads/2016/09/Belhar-study_guide.pdf

McGrath, A.E., 2013, Christian history: An introduction, Wiley-Blackwell, Chichester.

Mennoknight, 2013, Charismatic Primer 12 - Global megachurches by continent Africa, viewed 26 October 2016, from https://mennoknight.wordpress. com/2013/10/08/charismatic-primer-12-global-megachurches-by-continentafrical

Mills, W.E. (ed.), 1990, Mercer dictionary of the Bible, Mercer University Press, Macon, GA.

Nearing Colob, 2014, The Maasai creed, viewed 26 October 2016, from http://www. nearingkolob.com/maasai-creed/

Oden, T.C., 2007, How Africa shaped the Christian mind: The African seedbed of Western Christianity, InterVarsity Press, Downers Grove, IL.

Oden, T.C., 2011a, The African memory of Mark: Reassessing early church tradition, InterVarsity Press, Downers Grove, IL.

Oden, T.C., 2011b, Early Libyan Christianity: Uncovering a North African tradition, InterVarsity Press, Downers Grove, IL.

Okon, E.E., 2014, 'Christian missions and colonial rule in Africa: Objective and contemporary analysis', European Scientific Journal 10(17), 192-209.

Oliver, W.H., 2014, 'Reconsidering the skin colour (race) of Jesus and his ancestors', Journal of Early Christian History 4(2), 95-115.

Oliver, W.H., 2015, 'The heads of the Catechetical School in Alexandria', Verbum et Ecclesia 36(1), Art. \#1386, 1-14. https://doi.org/10.4102/ve.v36i1.1386 
Oppenheimer, S., 2003, Out of Africa's Eden, Jonathan Ball Publisher, Jeppestown. Pakenham, T., 1991, The scramble for Africa, Random House Inc., New York. Ritter, G., 1985, Luther, Fischer Taschenbuch, Frankfurt am Main.

Rodney, W., 1972, How Europe underdeveloped Africa, L'ouverture, London.

Sanneh, L., 1990, Translating the message: The missionary impact on culture, Maryknoll, New York.

Schaeffer, F.A., 1969, Death in the city, Inter-Varsity Press, Chicago, IL.

Schaff, P. (ed.), 1885, Ante-Nicene fathers. Vol. 6: Gregory Thaumaturgus; Dionysius the Great; Julius Africanus; Anatolius and minor writers; Methodius; Arnobius, Christian Classics Ethereal Library, Grand Rapids, MI.

Schilling, H., 1992, Religion, political culture and the emergence of early modern society: Essays in German and Dutch history, EJ Brill, Leiden.

Scholten, C., 1995, 'Die alexandrinische Katechetenschule', Jahrbuch für Antike und Christentum 38, 16-37.

Shaull, R., 1991, The reformation and liberation theology: Insights for the challenges of today, Westminster/John Knox Press, Louisville, KY.

Tloka, J., 2006, Griechische Christen, Christliche Griechen, Mohr Siebeck, Tübingen.
Trueblood, E., 1952, Your other vocation, Harper and Brothers, New York.

Van den Broek, R., 1995, 'The Christian "School" of Alexandria in the second and third centuries', in J.W. Drijvers \& A.A. MacDonald (eds.), Centers of learning: Learning and location in pre-modern Europe and the near east, pp. 39-47, EJ Brill, Leiden.

Van den Broek, R., 1996, Studies in Gnosticism and Alexandrian Christianity (Nag Hammadi and Manichaean Studies 39), EJ Brill, Leiden.

Van den Hoek, A., 1996, 'Techniques of quotation in Clement of Alexandria: A view of ancient literary working methods', Vigiliae Christianae 50, 223-243. https://doi. org/10.1163/157007296X00184

Van den Hoek, A., 1997, 'The "Catechetical" school of early Christian Alexandria and its philonic heritage', Harvard Theological Review 90(1), 59-87. https://doi. its philonic heritage', Harvard Theo
org/10.1017/S0017816000006180

Verdoner, M., 2014, 'The defenders of Christianity in the Ecclesiastical history of Eusebius', in D. Brakke, A.-C. Jacobsen \& J. Ulrich (eds.), Early Christianity in the context of Antiquity. Vol. 15: In defence of Christianity: Early Christian apologists, pp. 239-251, Peter Lang GmbH Europäischer Verlag der Wissenschaften, Frankfurt pp. 239-2
am Main.

Whelan, I., 2005, The Bible war in Ireland: The 'Second Reformation' and the polarization of Protestant-Catholic relations, 1800-1840, The University of Wisconsin Press, Madison, WI. 